\title{
Distribution of age at death in children with congenital heart disease who died before the age of 15
}

\author{
MILAN SAMÁNEK, * DAGMAR BENEŠOVÁ,† JANA GOETZOVÁ,ł \\ IVANA HRYCEJOVÅ§
}

From the ${ }^{\star}$ Centre of Paediatric Cardiology and Cardiovascular Surgery; and $\dagger$ Department of Pathological Anatomy, University Hospital Motol; $¥$ Municipal Department of Paediatric Cardiology; and the §Research Institute of Child Development, Charles University, Prague, Czechoslovakia

SUMMARY In the 27 years from 1952 to 1979 (before the introduction of advanced cardiac surgery) all children in Central Bohemia (population 1.2 million) who died before the age of 15 were examined at necropsy. Period death rates at various ages were calculated in those with congenital heart disease. Nearly all the deaths $(848,89.6 \%)$ occurred in the first year. Forty three $(44 \%$ of survivors) died in the second year and 17 (31\% of survivors) died between the second and fifth years. Over half $(20)$ of the survivors died between the fifth and tenth years. Nearly half $(44 \cdot 2 \%)$ of those born with congenital heart disease who died before the age of 15 died in the first four weeks. About a third (29.1\%) died in the first week and period death rates were $9 \cdot 7 \%, 7 \cdot 6 \%$, and $5.7 \%$ for the second, third, and fourth weeks respectively. In neonates death rates were highest in those with hypoplastic left heart syndrome $(89 \cdot 2 \%)$, coarctation of the aorta $(66 \cdot 7 \%)$, truncus arteriosus $(61 \cdot 8 \%)$, double outlet right ventricle $(57 \cdot 1 \%)$, and pulmonary atresia $(56.3 \%)$.

A necrospy was performed on all children who died in Central Bohemia (population 1.2 million) before the age of 15 in a 27 year period from 1952 to 1979. We reviewed the data on children with congenital heart disease, which were collected before the introduction of advanced cardiac surgery. The distribution of the congenital heart malformations found in the dead children has been reported elsewhere. ${ }^{1}$

In the present study we examine the distribution of the age at death in children who died before the age of 15 and in whom various congenital heart defects were found at necropsy.

\section{Patients and methods}

Central Bohemia, the area around Prague, has a population of 1.2 million and has industrial and agricultural regions. The largest town has 70000 inhabitants. During the 27 years of the study there was little movement of population into or out of the area. All children who died from 1952 to 1979, either at home or in a hospital, before they were 15 were

Requests for reprints to Professor Milan Samánek, Kardiocentrum, University Hospital Motol, 15018 Prague 5, Czechoslovakia.

Accepted for publication 5 November 1987 examined at necropsy. The necropsy was done or supervised by DB. Congenital heart disease was found in 946 liveborn children. The necropsy protocols were analysed carefully and some cases were reclassified to comply with the contemporary nomenclature. ${ }^{1}$ In a complex congenital heart disease the malformation that determined a haemodynamic function was regarded as dominant.

Before 1979 only children with ductus arteriosus were treated by operation. Three children in our study died after operation for closure of the ductus arteriosus. In 1952 shunt operations were introduced for the treatment of older children, and from 1968 they were used to treat infants. Fourteen of the deaths in our study occurred in children with a systemic to pulmonary anastomoses. Banding of the pulmonary artery was first performed in 1964 and all eight children who died after the banding are included in this study. Until 1970 coarctation of the aorta was treated surgically only in children over three years of age. Twelve children died after open heart surgery for tetralogy of Fallot. There were three deaths after operation for ventricular septal defect and three after correction of atrial septal defect and pulmonary stenosis. Balloon atrial septostomy was introduced in 1967; this was the technique that had been used in 14 patients with transposition of the great arteries, in three with pulmonary atresia, and in 
Table 1 Period death rates in children with various congenital heart diseases who died before the age of 15 in Central Bohemia

\begin{tabular}{|c|c|c|c|c|c|c|}
\hline \multirow[b]{2}{*}{ Heart disease } & \multirow[b]{2}{*}{ No } & \multicolumn{5}{|c|}{ Period of life (years) } \\
\hline & & $0-1(\%)$ & $1-2(\%)$ & $2-5(\%)$ & $5-10(\%)$ & $10-15(\%)$ \\
\hline $\begin{array}{l}\text { Aortic stenosis } \\
\text { Atrial septal defect } \\
\text { Atrioventricular septal defect } \\
\text { Coarctation of the aorta } \\
\text { Double outlet right ventricle } \\
\text { Hypoplastic left heart syndrome } \\
\text { Ductus arteriosus } \\
\text { Pulmonary atresia } \\
\text { Pulmonary stenosis } \\
\text { Single ventricle } \\
\text { Tetralogy of Fallot } \\
\text { Total anomalous pulmonary venous connection } \\
\text { Transposition of the great arteries } \\
\text { Tricuspid atresia } \\
\text { Truncus arteriosus } \\
\text { Ventricular septal defect } \\
\text { Others } \\
\text { All }\end{array}$ & $\begin{array}{r}26 \\
47 \\
60 \\
57 \\
42 \\
102 \\
34 \\
48 \\
10 \\
32 \\
69 \\
24 \\
100 \\
14 \\
34 \\
203 \\
44 \\
946\end{array}$ & \begin{tabular}{|l|}
$76 \cdot 9$ \\
$78 \cdot 7$ \\
$93 \cdot 3$ \\
$96 \cdot 5$ \\
$92 \cdot 9$ \\
100 \\
$88 \cdot 2$ \\
$93 \cdot 8$ \\
$70 \cdot 0$ \\
$87 \cdot 5$ \\
$53 \cdot 6$ \\
$95 \cdot 8$ \\
$99 \cdot 0$ \\
$71 \cdot 4$ \\
$94 \cdot 1$ \\
$91 \cdot 1$ \\
$97 \cdot 7$ \\
$89 \cdot 6$
\end{tabular} & $\begin{array}{c}33 \cdot 3 \\
70 \cdot 0 \\
75 \cdot 0 \\
00 \cdot 0 \\
33 \cdot 3 \\
\\
50 \cdot 0 \\
66 \cdot 7 \\
33 \cdot 3 \\
75 \cdot 0 \\
31 \cdot 3 \\
100 \\
100 \\
100 \\
50 \cdot 0 \\
27 \cdot 8 \\
100 \\
44 \cdot 0\end{array}$ & $\begin{array}{c}00 \cdot 0 \\
66 \cdot 7 \\
100 \\
00 \cdot 0 \\
00 \cdot 0 \\
00 \cdot 0 \\
00 \cdot 0 \\
00 \cdot 0 \\
100 \\
18 \cdot 2\end{array}$ & $\begin{array}{c}25 \cdot 0 \\
00 \cdot 0 \\
50 \cdot 0 \\
50 \cdot 0 \\
50 \cdot 0 \\
00 \cdot 0 \\
100 \\
61 \cdot 1\end{array}$ & $\begin{array}{l}100 \\
100 \\
100 \\
100 \\
100 \\
100\end{array}$ \\
\hline
\end{tabular}

one with supracardiac total anomalous pulmonary venous connection.

We calculated the period death rates for various age groups - the number of deaths in a given period calculated as a percentage of those who were alive at the start of the period.

\section{Results}

AGE AT DEATH IN CHILDREN WITH CONGENITAL HEART DISEASE WHO DIED BEFORE THE AGE OF 15

All heart diseases

Nearly all the deaths $(848,89.6 \%)$ occurred in the first year of life (table 1$)$. Nearly half $(43,44 \%)$ of those who survived the first year died in the second year and a third $(17,31 \%)$ of those surviving the second year died before they were six years old. Over half $(20,54 \%)$ the survivors died between the fifth and tenth years of life. The remainder died before reaching the age of 15 .

Nearly half $(44 \%)$ of those born with congenital heart disease died in the first four weeks (table 2). A fifth of the survivors of the neonatal period died in the second month. The next highest period death rate $(19.9 \%)$ was in the fourth month. Period death rates for the third month and between the fifth and seventh months ranged from $16.3 \%$ to $17 \cdot 9 \%$. Period death rates were lower from the seventh month onwards.

In total, $29.1 \%$ of the children with heart disease

Table 2 Period death rates in infants with various congenital heart diseases

\begin{tabular}{|c|c|c|c|c|c|c|c|c|c|c|c|c|c|}
\hline \multirow[b]{2}{*}{ Heart disease } & \multirow[b]{2}{*}{ No } & \multicolumn{12}{|c|}{ Period of life (months) } \\
\hline & & $\begin{array}{l}0-1 \\
(\%)\end{array}$ & $\begin{array}{l}1-2 \\
(\%)\end{array}$ & $\begin{array}{l}2-3 \\
(\%)\end{array}$ & $\frac{3-4}{(\%)}$ & $\begin{array}{l}4-5 \\
(\%)\end{array}$ & $\begin{array}{l}5-6 \\
(\%)\end{array}$ & $\begin{array}{l}6-7 \\
(\%)\end{array}$ & $\begin{array}{l}7-8 \\
(\%)\end{array}$ & $\begin{array}{l}8-9 \\
(\%)\end{array}$ & $\begin{array}{l}9-10 \\
(\%)\end{array}$ & $\begin{array}{l}10-11 \\
(\%)\end{array}$ & $\begin{array}{l}11-120 \\
(\%)\end{array}$ \\
\hline $\begin{array}{l}\text { Aortic stenosis } \\
\text { Atrial septal defect } \\
\text { Atrioventricular septal defect } \\
\text { Coarctation of the aorta } \\
\text { Double outlet right ventricle } \\
\text { Hypoplastic left heart syndrome } \\
\text { Ductus arteriosus } \\
\text { Pulmonary atresia } \\
\text { Pulmonary stenosis } \\
\text { Single ventricle } \\
\text { Tetralogy of Fallot } \\
\text { Total anomalous pulmonary venous }\end{array}$ & $\begin{array}{r}26 \\
47 \\
60 \\
57 \\
42 \\
102 \\
34 \\
48 \\
10 \\
32 \\
69\end{array}$ & $\begin{array}{l}42 \cdot 3 \\
29 \cdot 8 \\
16 \cdot 7 \\
66 \cdot 7 \\
57 \cdot 1 \\
89 \cdot 2 \\
11 \cdot 8 \\
56 \cdot 3 \\
30 \cdot 0 \\
18 \cdot 8 \\
23 \cdot 2\end{array}$ & $\begin{array}{r}20 \cdot 0 \\
12 \cdot 1 \\
8 \cdot 0 \\
21 \cdot 1 \\
17 \cdot 6 \\
54 \cdot 5 \\
23 \cdot 3 \\
28 \cdot 6 \\
00 \cdot 0 \\
19 \cdot 2 \\
11 \cdot 3\end{array}$ & $\begin{array}{r}16 \cdot 7 \\
13 \cdot 8 \\
15 \cdot 2 \\
13 \cdot 3 \\
35 \cdot 7 \\
00 \cdot 0 \\
27 \cdot 3 \\
20 \cdot 0 \\
00 \cdot 0 \\
19 \cdot 0 \\
2 \cdot 1\end{array}$ & $\begin{array}{r}20.0 \\
4.0 \\
23 \cdot 1 \\
23 \cdot 0 \\
44.4 \\
40.0 \\
37.5 \\
16.7 \\
14.3 \\
5.9 \\
4.4\end{array}$ & $\begin{array}{r}12 \cdot 5 \\
29 \cdot 2 \\
20 \cdot 0 \\
20 \cdot 0 \\
25 \cdot 0 \\
00 \cdot 0 \\
10 \cdot 0 \\
50 \cdot 0 \\
16 \cdot 7 \\
12.5 \\
9.1\end{array}$ & $\begin{array}{r}00.0 \\
11.8 \\
25.0 \\
12.5 \\
00.0 \\
33.3 \\
10.5 \\
20.0 \\
00.0 \\
28.0 \\
5.0\end{array}$ & $\begin{array}{r}00.0 \\
13.3 \\
22.2 \\
28.6 \\
25.0 \\
00.0 \\
28.6 \\
25.0 \\
00.0 \\
10.0 \\
2.6\end{array}$ & $\begin{array}{r}14.3 \\
77 \cdot 0 \\
14.3 \\
00 \cdot 0 \\
00 \cdot 0 \\
50 \cdot 0 \\
20 \cdot 0 \\
00 \cdot 0 \\
20 \cdot 0 \\
11 \cdot 1 \\
8.1\end{array}$ & $\begin{array}{r}00.0 \\
8.3 \\
33.3 \\
20.0 \\
00 \cdot 0 \\
00 \cdot 0 \\
00.0 \\
00.0 \\
25 \cdot 0 \\
00.0 \\
5.9\end{array}$ & $\begin{array}{c}00 \cdot 0 \\
00 \cdot 0 \\
25 \cdot 0 \\
50 \cdot 0 \\
00 \cdot 0 \\
100 \\
00 \cdot 0 \\
00 \cdot 0 \\
00 \cdot 0 \\
37 \cdot 5 \\
00 \cdot 0\end{array}$ & $\begin{array}{l}00.0 \\
00.0 \\
00.0 \\
00.0 \\
00.0 \\
\\
00.0 \\
00.0 \\
00.0 \\
20.0 \\
00.0\end{array}$ & 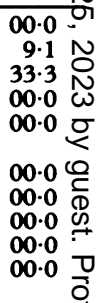 \\
\hline $\begin{array}{l}\text { connection } \\
\text { Transposition of the great arteries } \\
\text { Tricuspid atresia } \\
\text { Truncus arteriosus } \\
\text { Ventricular septal defect } \\
\text { Others } \\
\text { All }\end{array}$ & $\begin{array}{r}24 \\
100 \\
14 \\
34 \\
203 \\
44 \\
946\end{array}$ & $\begin{array}{l}41 \cdot 7 \\
47 \cdot 0 \\
21 \cdot 4 \\
61 \cdot 8 \\
36 \cdot 9 \\
40 \cdot 9 \\
44 \cdot 2\end{array}$ & $\begin{array}{l}30 \cdot 8 \\
43 \cdot 4 \\
18 \cdot 2 \\
30 \cdot 8 \\
18 \cdot 0 \\
19 \cdot 2 \\
20 \cdot 6\end{array}$ & $\begin{array}{l}44 \cdot 4 \\
26 \cdot 7 \\
11 \cdot 1 \\
11 \cdot 1 \\
21 \cdot 0 \\
33 \cdot 3 \\
17 \cdot 9\end{array}$ & $\begin{array}{l}40 \cdot 0 \\
22 \cdot 7 \\
12 \cdot 5 \\
37 \cdot 5 \\
25 \cdot 3 \\
21 \cdot 4 \\
19 \cdot 9\end{array}$ & $\begin{array}{r}00 \cdot 0 \\
11 \cdot 8 \\
00 \cdot 0 \\
00 \cdot 0 \\
22 \cdot 6 \\
9 \cdot 1 \\
17 \cdot 2\end{array}$ & $\begin{array}{l}00 \cdot 0 \\
20 \cdot 0 \\
14 \cdot 3 \\
25 \cdot 0 \\
20 \cdot 4 \\
20 \cdot 0 \\
16 \cdot 3\end{array}$ & $\begin{array}{l}33.3 \\
33.3 \\
16.7 \\
00 \cdot 0 \\
25.6 \\
25 \cdot 0 \\
16.8\end{array}$ & $\begin{array}{l}00 \cdot 0 \\
12.5 \\
20.0 \\
00 \cdot 0 \\
10.3 \\
00 \cdot 0 \\
10.1\end{array}$ & $\begin{array}{l}00 \cdot 0 \\
42 \cdot 9 \\
00 \cdot 0 \\
00 \cdot 0 \\
15 \cdot 3 \\
33 \cdot 3 \\
12 \cdot 7\end{array}$ & $\begin{array}{l}50 \cdot 0 \\
00 \cdot 0 \\
00 \cdot 0 \\
00 \cdot 0 \\
13.6 \\
25.0 \\
10.5\end{array}$ & $\begin{array}{r}00 \cdot 0 \\
00 \cdot 0 \\
00 \cdot 0 \\
00 \cdot 0 \\
34.5 \\
33.3 \\
2.7\end{array}$ & 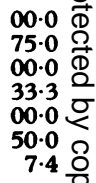 \\
\hline
\end{tabular}


Table 3 Period death rates in neonates (1 to 4 weeks old) with various congenital heart diseases

\begin{tabular}{|c|c|c|c|c|c|}
\hline \multirow[b]{2}{*}{ Heart disease } & \multirow[b]{2}{*}{ No } & \multicolumn{4}{|c|}{ Period of life (weeks) } \\
\hline & & $0-1(\%)$ & $1-2(\%)$ & $2-3(\%)$ & $3-4(\%)$ \\
\hline $\begin{array}{l}\text { Aortic stenosis } \\
\text { Atrial septal defect } \\
\text { Atrioventricular septal defect } \\
\text { Coarctation of the aorta } \\
\text { Double outlet right ventricle } \\
\text { Hypoplastic left heart syndrome } \\
\text { Ductus arteriosus } \\
\text { Pulmonary atresia } \\
\text { Pulmonary stenosis } \\
\text { Single ventricle } \\
\text { Tetralogy of Fallot } \\
\text { Total anomalous pulmonary venous connection } \\
\text { Transposition of the great arteries } \\
\text { Tricuspid atresia } \\
\text { Truncus arteriosus } \\
\text { Ventricular septal defect } \\
\text { Others } \\
\text { All }\end{array}$ & $\begin{array}{r}26 \\
47 \\
60 \\
57 \\
42 \\
102 \\
34 \\
46 \\
10 \\
32 \\
69 \\
24 \\
100 \\
14 \\
34 \\
203 \\
44 \\
946\end{array}$ & $\begin{array}{r}26 \cdot 9 \\
17 \cdot 0 \\
6 \cdot 7 \\
35 \cdot 1 \\
75 \cdot 0 \\
68 \cdot 6 \\
2 \cdot 9 \\
58 \cdot 3 \\
30 \cdot 0 \\
3 \cdot 1 \\
17 \cdot 4 \\
4 \cdot 2 \\
27 \cdot 0 \\
7 \cdot 1 \\
44 \cdot 1 \\
73 \cdot 9 \\
31 \cdot 8 \\
29 \cdot 1\end{array}$ & $\begin{array}{r}15 \cdot 8 \\
5 \cdot 1 \\
3 \cdot 6 \\
18 \cdot 9 \\
25 \cdot 0 \\
34 \cdot 4 \\
00 \cdot 0 \\
14 \cdot 3 \\
00 \cdot 0 \\
6 \cdot 5 \\
1 \cdot 8 \\
8 \cdot 7 \\
12 \cdot 3 \\
7 \cdot 7 \\
15 \cdot 8 \\
6 \cdot 0 \\
10 \cdot 0 \\
9 \cdot 7\end{array}$ & $\begin{array}{r}6 \cdot 3 \\
5 \cdot 4 \\
7 \cdot 4 \\
26 \cdot 6 \\
00 \cdot 0 \\
23 \cdot 8 \\
00 \cdot 0 \\
12 \cdot 5 \\
00 \cdot 0 \\
6 \cdot 9 \\
1 \cdot 8 \\
23 \cdot 8 \\
11 \cdot 1 \\
00 \cdot 0 \\
6 \cdot 3 \\
4.3 \\
3.7 \\
7.6\end{array}$ & $\begin{array}{r}00 \cdot 0 \\
5.7 \\
00.0 \\
13.6 \\
00.0 \\
31 \cdot 3 \\
9.1 \\
00 \cdot 0 \\
00 \cdot 0 \\
3.7 \\
3.6 \\
13.3 \\
7.0 \\
8.3 \\
13.3 \\
5.2 \\
00.0 \\
5.7\end{array}$ \\
\hline
\end{tabular}

that we studied were dead by the end of the first week. The period death rates for the second, third, and fourth weeks were $9.7 \%, 7.6 \%$, and $5.7 \%$ respectively.

\section{Heart disease categories}

In neonates the highest death rates $(89 \cdot 2 \%)$ occurred in those with hypoplastic left heart syndrome (table 2). Coarctation of the aorta, truncus arteriosus, double outlet right ventricle, and pulmonary atresia were associated with death rates of $>50 \%$. Death rates were lower in those with ductus arteriosus, atrioventricular septal defect, and single ventricle (table 3).

Period death rates in the second month of life also showed the highest rates for hypoplastic left heart (table 2); but coarctation of the aorta fell from the second most highest rate to the seventh. It was replaced in second place by transposition of the great arteries. The third highest period death rate $(30.8 \%)$ for those who survived the first month of life was found in those with total anomalous pulmonary venous connection and truncus arteriosus. Pulmonary atresia remained in fifth position. No child with isolated pulmonary stenosis died in the second month of life. In the second month, period death rates for atrioventricular septal defect, tetralogy of Fallot, and atrial septal defect were very low.

Nearly all the deaths occurred in the first year after birth, but there was variation in period death rates for different heart diseases (table 1). All children with the hypoplastic left heart syndrome died during this period, as did $>90 \%$ of those with transposition of the great arteries, coarctation of the aorta, total anomalous pulmonary venous connection, truncus arteriosus, pulmonary atresia, atrioventricular septal defect, double outlet right ventricle, and ventricular septal defect.

\section{DEATH RATES ASSOCIATED WITH DIFFERENT HEART DISEASES}

In patients in whom ventricular septal defect was diagnosed at necropsy the highest period death rate occurred in the first month (table 2 ). In the second month the death rate was halved and for the third to seventh months of age period death rates ranged from 20.4 to $25 \cdot 6 \%$. After this period period death rates were low, except in the eleventh month. In those who survived infancy the period death rate was lowest $(27.8 \%)$ in the second year of life (table 1$)$.

Most $(89 \cdot 2 \%)$ children with the hypoplastic left heart syndrome did not survive the first month of life (table 2), and period death rates remained high throughout infancy. The remainder of those dying before they were 15 died in the tenth month of life.

Forty seven per cent of children born with transposition of the great arteries who died before they reached 15 died in the neonatal period (table 2). The period death rate was high in the first week (table 3 ). The period death rate in the second month was only slightly lower $(43.4 \%)$ and it became lower during the next three months. The period death rate was highest in the patients who survived till the end of the first year. The rest of the patients died in the second year of life (see table 1).

Those who died with tetralogy of Fallot had the lowest $(53.6 \%)$ period death rate in infancy of all the categories of heart disease. Later in childhood period death rates in children with this defect became higher (table 1).

The period death rate in children with atrioven- 
584

tricular septal defects was one of the lowest in the first two months. This increased from the fourth month and the last patients died between the second and fifth years of life (table 1 ).

In the first year of life the period death rate $(96.5 \%)$ in those with coarctation of the aorta was the third highest for any disease category (table 1). In neonates coarctation of the aorta had the second highest period death rate (table 2). During the first to the eighth months it varied between 12.5 and $28.6 \%$. No patient died in the period from the eleventh month to the fifth year of age.

More than half of patients $(58.3 \%)$ with pulmonary atresia died in the first postnatal week (table 3). Period death rates were high in the first seven months of life. In total $93.8 \%$ of those with fatal pulmonary atresia died in infancy. Those who survived the first two years of life tended to survive until they were 15.

Period death rates in children with atrial septal defect were $78.7 \%$ in the first year and 70.0 and $66.7 \%$ in the two succeeding periods (1-2 and $2-5$ years). In infancy the period death rate was lowest in the later months.

Most $(92.9 \%)$ children with double outlet right ventricle died in the first seven months of life (tables 1 and 2). The period death rate in the second year of life dropped to $33.3 \%$.

For children with truncus arteriosus the period death rate was highest $(94 \cdot 1 \%)$ in the first year of life, especially in the first four months (tables 1 and 2). The last patient died before the age of five.

All patients who died in childhood with total anomalous pulmonary venous connection or tricuspid atresia died in the first two years of life (table 1). All those with a single ventricle were dead before the age of five. Period death rates in those with ductus arteriosus were high early in infancy and very low in the last four months of infancy and between the second and fifth years of life. Period death rates for aortic stenosis were highest in the first five months.

\section{Discussion}

We studied a group of children with heart disease
Samánek, Benešová, Goetzová, Hrycejová

who died before the age of 15 . Our data on the mortality of children with a heart disease and the incidence of congenital heart disease show that such cases make up about one third of all children born with heart disease.

Table 4 compares our results with those of other studies of mortality in children with a congenital heart disease. ${ }^{2-8}$ The period death rate in the first week after birth ranges from $27 \%$ to $54 \%$. Our figures for the first week and first month are higher than those of Kerrebijn ${ }^{6}$ but lower than those of all other reports. At the end of the first year of life the period death rate in our series was within the reported range but it was higher than the mean period death rate of $84 \%$ for all reported studies. Our series has the advantage of being more than four times larger than the largest series reported so far and of giving complete coverage of all deaths, both in hospital and at home. We also had systematic coverage of total child deaths, which excludes various selection bias of other studies.

The duration of the study (27 years) eliminates possible year to year variations in the period death rates and disease specific death rates. The decline in infant mortality in Central Bohemia from 30 per 1000 of liveborn children in 1952 to $15 \cdot 7 / 1000$ in 1979 may have influenced our results. There was not a proportional decrease in the mortality of children with congenital heart disease. On the contrary, the proportion of deaths from congenital heart disease increased from $4.7 \%$ of total deaths in 1952 to $7.8 \%$ in the last five years of the study.

We studied a period before surgical treatment could have had an appreciable effect on death rates. Only period death rates in those with ductus arteriosus were likely to have been affected by surgical treatment. Nevertheless, operations for ductus arteriosus were only done occasionally in infancy when the period death rate was highest and so such interventions are unlikely to have significantly changed the results. Similarly, the anastomosing operations for tetralogy of Fallot, which were done only in older children until 1968 and in a very limited number of patients below the age of four years in the

Table 4 Period death rates (\%) in children with congenital heart disease reported in other series

\begin{tabular}{|c|c|c|c|c|c|c|}
\hline \multirow[b]{2}{*}{ Authors } & \multirow[b]{2}{*}{ Reference } & \multirow[b]{2}{*}{ No of cases } & \multicolumn{4}{|l|}{ Age } \\
\hline & & & 1 week & 1 month & 1 year & 15 year \\
\hline $\begin{array}{l}\text { Carlgren } \\
\text { Feldt et al } \\
\text { Gardiner and Keith } \\
\text { Hoffiman and Christianson } \\
\text { Kerrebijn } \\
\text { Mustacchi et al } \\
\text { Renwick et al } \\
\text { Samánek }\end{array}$ & $\begin{array}{l}2 \\
3 \\
4 \\
5 \\
6 \\
7 \\
8 \\
\text { This study }\end{array}$ & $\begin{array}{r}145 \\
81 \\
29 \\
43 \\
15 \\
171 \\
206 \\
946\end{array}$ & $\begin{array}{l}36 \\
54 \\
\frac{2}{27} \\
\frac{40}{29}\end{array}$ & $\begin{array}{l}56 \\
70 \\
55 \\
51 \\
40 \\
49 \\
44\end{array}$ & $\begin{array}{l}86 \\
92 \\
83 \\
80 \\
82 \\
83 \\
90\end{array}$ & $\begin{array}{l}100 \\
100 \\
100 \\
100 \\
100 \\
100 \\
100 \\
100\end{array}$ \\
\hline
\end{tabular}


last years of study, could not have influenced the results markedly. A balloon atrial septostomy can postpone but not change the unfavourable outcome of transposition of the great arteries, and period death rates before and after 1967 (when the septostomy was introduced) did not differ significantly.

The finding of heart disease at necropsy does not necessarily mean that it, rather than another lethal disease, was the cause of death. In an earlier report we found that heart disease could have been responsible for death in only $45 \%$ of those neonates in whom a heart malformation was found at necropsy. ${ }^{9}$

We thank Professor F J Macartney for stimulating us to write this paper and for his help with processing the statistical data.

\section{References}

1 Samánek M, Goetzová J, Benešová D. Distribution of congenital heart malformations in an autopsied child population. Int J Cardiol 1985;8:235-48.

2 Carlgren L-E. The incidence of congenital heart disease in children born in Gothenburg 1941-1950. Br Heart $J$ 1959;21:40-50.

3 Feldt RH, Avasthey P, Yoshimasu F, Kurland LT, Titus JL. Incidence of congenital heart disease in children born to residents of Olmsted Country, Minnesota 1950-1969. Mayo Clin Proc 1971;46: 794-9.

4 Gardiner JH, Keith JD. Prevalence of heart disease in Toronto children: 1948-1949 cardiac registry. Pediatrics 1951;7:713-21.

5 Hoffman JIE, Christianson R. Congenital heart disease in a cohort of 19502 births with long-term follow-up. Am J Cardiol 1978;42:641-7.

6 Kerrebijn KF. Incidence in infants and mortality from congenital malformations of the circulatory system. Acta Paediatr Scand 1966;55:316-20.

7 Mustacchi P, Sherins RS, Miller MJ. Congenital malformations of the heart and the great vessels. JAMA 1963;183:241-4.

8 Renwick DHG, Miller JR, Paterson D. Estimates of incidence and prevalence of mongolism and of congenital heart disease in British Columbia. Can Med Assoc J 1964;91:365-71.

9 Samánek M, Goetzová J, Benešová $D$. Causes of death in neonates born with a heart malformation. Int $J$ Cardiol 1986;11:63-74. 